\title{
ABO BLOOD GROUPS AND Rh ISO-IMMUNIZATION
}

\author{
BY \\ T. M. ALLAN \\ Blood Transfusion Centre, Royal Infirmary, Aberdeen
}

Levine (1943, 1958a, b, 1959) observed that $\mathrm{Rh}$ isoimmunization of $R$ h-negative women was relatively much more common in women with ABO-compatible husbands than in women with ABO-incompatible husbands. This observation has implications with regard to the incidence of the ABO blood groups in affected families, and certain of these implications were first noted by Lucia and Hunt (1950a, b) in respect of mothers, by Donohue, Mullinger, Cook, and Snelling (1954) in respect of babies, and by Davidsohn, Stern, and Mackeviciute (1958) in respect of fathers. In what follows some of the other implications are noted, on the basis of aggregation of all known series, and an appendix gives what evidence exists as yet on the sex ratio of affected babies and their sensitizing sibs. With the exception of the series reported by Cohen (1960), which is approximately 8 per cent. Negro, all the available series are
White. The relevance of this fact is dealt with briefly later.

\section{MatingS}

There has been abundant confirmation of Levine's observation that $R h$ iso-immunization is relatively much more frequent in wives with ABO-compatible husbands than in those with ABO-incompatible husbands (Race and Sanger, 1962). Recently, however, Levine's observation has been confirmed with reference not only to ABO-incompatibility as such but also to particular ABO blood group combinations of husband and wife. Thus Reepmaker, Nijenhuis, and van Loghem (1962), in an analysis of the earlier data of Reepmaker himself (1955), showed that there was a deficit in each of the seven ABO-incompatible mating classes separately. The details are given in Table I, and the same Table

TABLE I

ABO BLOOD GROUP INCIDENCE OF MATINGS IN Rh HAEMOLYTIC DISEASE OF THE NEWBORN

\begin{tabular}{|c|c|c|c|c|c|c|c|}
\hline \multirow[t]{2}{*}{ Matings } & \multirow{2}{*}{$\begin{array}{c}\text { Fathers } \\
\times \\
\text { Mothers }\end{array}$} & \multicolumn{3}{|c|}{$\begin{array}{c}\text { Data of Reepmaker } \\
(1955)\end{array}$} & \multicolumn{3}{|c|}{$\begin{array}{c}\text { Combined Data of } \\
\text { Malone (1949), } \\
\text { Davidsohn and others (1958), and } \\
\text { Cohen (1960) }\end{array}$} \\
\hline & & $\begin{array}{l}\text { Matings } \\
\text { Expected }\end{array}$ & $\begin{array}{l}\text { Matings } \\
\text { Observed }\end{array}$ & Observed & $\begin{array}{c}\text { Mothers } \\
\text { Not } \\
\text { Rh-Immunized }\end{array}$ & $\begin{array}{c}\text { Mothers } \\
\text { Rh-Immunized }\end{array}$ & $\frac{\mathrm{Rh}-I m m u n i z e d}{\text { Non-Immunized }}$ \\
\hline \multirow{4}{*}{$\underset{\text { Compatible }}{\text { ABO- }}$} & $\begin{array}{l}\mathbf{A B} \times \mathbf{A B} \\
\mathbf{B} \times \mathbf{B} \\
\mathbf{A} \times \mathbf{A} \\
\mathbf{O} \times \mathbf{O}\end{array}$ & $\begin{array}{r}1 \cdot 8 \\
13 \cdot 5 \\
322 \cdot 0 \\
353 \cdot 0\end{array}$ & $\begin{array}{r}3 \\
19 \\
404 \\
415\end{array}$ & $\begin{array}{l}1 \cdot 67 \\
1 \cdot 41 \\
1 \cdot 25 \\
1 \cdot 18\end{array}$ & $\begin{array}{r}6 \\
50 \\
926 \\
986\end{array}$ & $\begin{array}{r}5 \\
43 \\
418 \\
469\end{array}$ & $\begin{array}{l}0.83 \\
0.86 \\
0.45 \\
0.48\end{array}$ \\
\hline & Total & $690 \cdot 3$ & 841 & $1 \cdot 22$ & 1,968 & 935 & 0.48 \\
\hline & $\begin{array}{l}\mathbf{O} \times \mathbf{B} \\
\mathbf{O} \times \mathbf{A} \\
\hat{\boldsymbol{O}} \times \mathbf{A B} \\
\mathbf{B} \times \mathbf{A B} \\
\mathbf{A} \times \mathbf{A B}\end{array}$ & $\begin{array}{r}69.0 \\
337.0 \\
25 \cdot 0 \\
5 \cdot 0 \\
24 \cdot 0\end{array}$ & $\begin{array}{r}91 \\
435 \\
29 \\
5 \\
19\end{array}$ & $\begin{array}{l}1 \cdot 32 \\
1 \cdot 29 \\
1 \cdot 16 \\
1 \cdot 00 \\
0.79\end{array}$ & $\begin{array}{r}225 \\
963 \\
77 \\
23 \\
73\end{array}$ & $\begin{array}{r}99 \\
425 \\
41 \\
8 \\
42\end{array}$ & $\begin{array}{l}0.44 \\
0.44 \\
0.53 \\
0.35 \rightarrow \\
0.58\end{array}$ \\
\hline & Total & $460 \cdot 0$ & 579 & $1 \cdot 26$ & 1,361 & 615 & 0.45 \\
\hline \multirow[t]{2}{*}{$\underset{\text { Incompatible }}{\mathrm{ABO}}$} & $\begin{aligned} \mathbf{B} & \times \mathbf{A} \\
\mathbf{A} & \times \mathbf{B} \\
\mathbf{A B} & \times \mathbf{A} \\
\mathbf{A B} & \times \mathbf{A} \\
\mathbf{B} & \times \mathbf{O} \\
\mathbf{A} & \times \mathbf{O} \\
\mathbf{A B} & \times \mathbf{O}\end{aligned}$ & $\begin{array}{r}66 \cdot 0 \\
66 \cdot 0 \\
24.0 \\
5.0 \\
69.0 \\
337.0 \\
25.0\end{array}$ & $\begin{array}{r}48 \\
44 \\
15 \\
3 \\
40 \\
172 \\
0\end{array}$ & $\begin{array}{l}0.73 \\
0.67 \\
0.62 \\
0.60 \\
0.58 \\
0.51 \\
\infty\end{array}$ & $\begin{array}{r}232 \\
253 \\
83 \\
13 \\
255 \\
964 \\
90\end{array}$ & $\begin{array}{r}51 \\
57 \\
29 \\
6 \\
72 \\
277 \\
9\end{array}$ & $\begin{array}{l}0 \cdot 22 \\
0 \cdot 23 \\
0 \cdot 35 \\
0 \cdot 46-7 \\
0 \cdot 28 \\
0 \cdot 29 \\
0 \cdot 10\end{array}$ \\
\hline & Total & 592.0 & 322 & 0.54 & 1,890 & 501 & 0.27 \\
\hline
\end{tabular}


shows that a similar result is obtained from the aggregate of the three other comparable series reported so far. The left side of the Table gives the figures of Reepmaker and others (1962), the relative incidence of the various mating classes being here expressed as the ratio of their observed to their expected incidence in the general population. The right side of the Table gives the aggregate of the other three series, the relative incidence of the various mating classes being here expressed as the ratio of immunized to non-immunized mothers in each mating class. The Table shows that, in the aggregate of these three series (with the exception of the very small classes $B \times A B$ and $A B \times B$ ), the incidence of each of the seven ABO-incompatible classes is, as in Reepmaker's series, relatively lower than that of all nine of the ABO-compatible classes.

Special mention must be made of $A B$ father $\times O$ mother matings (foot of Table I). There are no such matings in Reepmaker's series, where approximately fourteen would be expected, and in the combined series of Malone (1949), Davidsohn and others (1958), and Cohen (1960) there are only nine, where approximately 25 would be expected. (These expected figures are based on the hypothesis that the matings concerned have the same probability of inclusion as the other ABO-incompatible matings.) This is the clearest possible evidence in favour of the hypothesis of Nevanlinna $(1952,1953)$ that, in general, ABO-incompatible babies are unable to $\mathrm{Rh}$ immunize their mothers. The evidence is the stronger in that, in all six of the $A B$ father $\times O$ mother matings in Cohen's series, the mother had either been transfused or had married twice (Cohen, 1960).

\section{FATHERS}

As all $\mathrm{O}$ husbands are $\mathrm{ABO}$-compatible with their wives (Table I) the wives of $\mathrm{O}$ husbands would be expected to have the greatest liability to $\mathrm{Rh}$ isoimmunization. This expectation was confirmed by Davidsohn and others (1958), who pointed out that in their series the incidence of $\mathbf{R h}$-immunized wives was significantly higher for $\mathrm{O}$ husbands than for $\mathrm{A}$, $B$, or AB husbands.

Similarly, as almost all AB husbands are ABOincompatible with their wives (Table I), the wives of AB husbands would be expected to be the least liable to Rh-immunization, as Levine (1958a, b) has pointed out.

In the same way, as relatively many more A than $B$ husbands, and $\mathrm{B}$ than AB husbands, have ABOcompatible wives, the expected descending order of relative incidence of $\mathrm{Rh}$-positive husbands with $\mathrm{Rh}$ immunized wives must be $\mathbf{O}-\mathbf{A}-\mathbf{B}-\mathbf{A B}$. This descending order is, in fact, found in both of the aggregates in Table II, which includes all the relevant series so far reported.

Chown (1948) and Heistö (1955) give the blood groups of the husbands, but not in relation to the blood groups of their wives.

\section{MOTHERS}

On the basis of Levine's observation, Lucia and Hunt $(1950 \mathrm{a}, \mathrm{b})$ pointed out that, as relatively many more $\mathrm{A}$ than $\mathrm{O}$ women have $\mathrm{ABO}$-compatible husbands (Table I), A women would be expected to be more liable than $\mathrm{O}$ women to $\mathrm{Rh}$ iso-immunization, and this was borne out by their own series. Previously, Chown (1948) had observed that in his own series the relatively highest incidence of $\mathrm{Rh}$ isoimmunization was in $\mathrm{AB}$ mothers, and this too accords with expectation.

Similarly, as relatively more A than B women, and $\mathrm{B}$ than $\mathrm{O}$ women, have $\mathrm{ABO}-$ compatible husbands, the expected descending order of relative incidence of $\mathrm{Rh}$-immunized wives must be $\mathrm{AB}-\mathrm{A}-\mathrm{B}-\mathrm{O}$.

TABLE II

ABO BLOOD GROUP INCIDENCE OF FATHERS OF BABIES WITH Rh HAEMOLYTIC DISEASE OF THE NEWBORN

\begin{tabular}{|c|c|c|c|c|c|c|c|}
\hline \multicolumn{2}{|c|}{$\begin{array}{l}\text { Descending Order } \\
\text { of Incidence } \\
\text { of Fathers }\end{array}$} & \multicolumn{3}{|c|}{$\begin{array}{c}\text { Combined Data of } \\
\text { Chown (1948), } \\
\text { van Loghem and Spaander (1948), } \\
\text { Reepmaker (1955), and } \\
\text { Heistö (1955) }\end{array}$} & \multicolumn{3}{|c|}{$\begin{array}{c}\text { Combined Data of } \\
\text { Malone (1949), } \\
\text { Davidsohn and others (1958), and } \\
\text { Cohen (1960) }\end{array}$} \\
\hline $\begin{array}{c}\text { Order } \\
\text { Expected }\end{array}$ & $\begin{array}{c}\text { Order } \\
\text { Observed }\end{array}$ & $\begin{array}{c}\text { Fathers } \\
\text { Expected }\end{array}$ & $\begin{array}{c}\text { Fathers } \\
\text { Observed }\end{array}$ & $\frac{\text { Observed }}{\text { Expected }}$ & $\begin{array}{l}\text { Husbands } \\
\text { with Non- } \\
\text { Immunized } \\
\text { Wives }\end{array}$ & $\begin{array}{c}\text { Husbands } \\
\text { with } \\
\text { Rh-Immunized } \\
\text { Wives }\end{array}$ & $\frac{\text { Rh-Immunized }}{\text { Non-Immunized }}$ \\
\hline $\mathbf{O}$ & 0 & $1,104 \cdot 7$ & 1,368 & $1 \cdot 24$ & 2,251 & 1,034 & 0.46 \\
\hline $\begin{array}{c}\mathbf{A} \\
\mathbf{B} \\
\mathbf{A B}\end{array}$ & $\begin{array}{c}\mathbf{A} \\
\mathbf{B} \\
\mathbf{A B}\end{array}$ & $\begin{array}{r}1,127 \cdot 3 \\
218 \cdot 5 \\
84 \cdot 1\end{array}$ & $\begin{array}{r}979 \\
155 \\
33\end{array}$ & $\begin{array}{l}0.87 \\
0.71 \\
0.39\end{array}$ & $\begin{array}{r}2,216 \\
560 \\
192\end{array}$ & $\begin{array}{r}794 \\
174 \\
49\end{array}$ & $\begin{array}{l}0 \cdot 36 \\
0 \cdot 31 \\
0 \cdot 26\end{array}$ \\
\hline Total & . & $2,534 \cdot 6$ & 2,535 & 1.00 & 5,219 & 2,051 & 0.39 \\
\hline
\end{tabular}


This descending order, is, in fact, found in both aggregates of Table III, which includes all the relevant series so far reported.

Two points may be added here for completeness:

(1) Wiener, Nappi, and Gordon (1953) found that the difference between $\mathrm{A}$ and $\mathrm{O}$ mothers in their series was very largely confined to mothers of sub-group $A_{1}$, but this was not confirmed by Heistö (1955), in a larger series.

(2) Levine $(1958 \mathrm{a}, \mathrm{b})$ found that $\mathrm{Rh}$-positive women with ABO-compatible husbands were more liable than Rh-positive women with ABO-incompatible husbands to become iso-immunized to the $R h$ antigen c. He also found (Levine, 1962) that Kellnegative women with $\mathrm{ABO}$-compatible husbands were more liable than Kell-negative women with ABO-incompatible husbands to become isoimmunized to the Kell antigen $\mathrm{K}$.

A somewhat different form of circumstantial evidence on the effect of the ABO blood groups in relation to maternal $R h$ iso-immunization is exemplified in the report by Newcombe (1963) on the distribution, according to maternal $\mathrm{ABO}$ and $\mathrm{Rh}$ blood group, of 53,100 live births and 27,260 foetal deaths (at all intra-uterine ages) in New York City, the live births being a 10 per cent. sample.

In accordance with the hypothesis that many embryos of Rh-positive mothers are at lethal risk as a result of $\mathrm{ABO}$-incompatibility with their mothers, and in accordance with the fact that foetuses of $\mathrm{Rh}$ positive mothers are rarely at risk in respect of $R \mathbf{h}$ incompatibility with their mothers, Newcombe found that, in regard to foetal death-rates, the descending order of relative incidence of $\mathrm{Rh}$-positive mothers was $\mathbf{O}-\mathbf{B}$ - A - AB (Table IV), though for B Rhpositive mothers the foetal death-rate was considerably lower than expected.

Similarly, in accordance with the above-mentioned hypothesis, and in accordance, further, with the fact that many foetuses of $\mathrm{Rh}$-negative mothers are at lethal risk as a result of $\mathrm{Rh}$-incompatibility with their mothers, but in accordance, finally, with the fact that many such foetuses are protected from this particular risk by concomitant ABO-incompatibility, Newcombe expected that, in regard to foetal deathrates, the descending order of relative incidence of $\mathrm{Rh}$-negative mothers would prove to be $\mathrm{AB}-\mathrm{A}$ $\mathrm{B}-\mathrm{O}-i . e$. the reverse of what he found in $\mathrm{Rh}$ positive mothers. Table IV shows that this expected result was, in fact, obtained in the case of $\mathrm{AB}, \mathrm{B}$,

TABLE III

ABO BLOOD GROUP INCIDENCE OF MOTHERS OF BABIES WITH Rh HAEMOLYTIC DISEASE OF THE NEWBORN

\begin{tabular}{|c|c|c|c|c|c|c|c|}
\hline \multicolumn{2}{|c|}{$\begin{array}{l}\text { Descending Order } \\
\text { of Incidence } \\
\text { of Mothers }\end{array}$} & \multicolumn{3}{|c|}{$\begin{array}{c}\text { Combined Data of } \\
\text { Chown (1948), } \\
\text { van Loghem and Spaander (1948), } \\
\text { Speiser and Jancik (1953), } \\
\text { Reepmaker (1955), } \\
\text { Heistö (1955), and } \\
\text { Grodecka, Marciniakówna, and Osinska (1960) }\end{array}$} & \multicolumn{3}{|c|}{$\begin{array}{c}\text { Combined Data of } \\
\text { Malone (1949), } \\
\text { Lucia and Hunt (1950a, b), } \\
\text { Wiener and others (1953), } \\
\text { Davidsohn and others (1958), and } \\
\text { Cohen (1960) }\end{array}$} \\
\hline $\begin{array}{c}\text { Order } \\
\text { Expected }\end{array}$ & $\begin{array}{c}\text { Order } \\
\text { Observed }\end{array}$ & $\begin{array}{l}\text { Mothers } \\
\text { Expected }\end{array}$ & $\begin{array}{l}\text { Mothers } \\
\text { Observed }\end{array}$ & $\frac{\text { Observed }}{\text { Expected }}$ & $\begin{array}{l}\text { Mothers Not } \\
\text { Rh-Immunized }\end{array}$ & $\begin{array}{c}\text { Mothers } \\
\text { Rh-Immunized }\end{array}$ & $\frac{\text { Rh-Immunized }}{\text { Non-Immunized }}$ \\
\hline$\stackrel{\mathbf{A B}}{\mathbf{A}}$ & $\underset{\mathbf{A}}{\mathbf{A B}}$ & $\begin{array}{r}148 \cdot 6 \\
1,524 \cdot 4\end{array}$ & $\begin{array}{r}178 \\
1,792\end{array}$ & $\begin{array}{l}1 \cdot 20 \\
1 \cdot 18\end{array}$ & $\begin{array}{r}258 \\
2,986\end{array}$ & $\begin{array}{r}123 \\
1,225\end{array}$ & $\begin{array}{l}0.48 \\
0 \cdot 41\end{array}$ \\
\hline $\begin{array}{l}\mathbf{B} \\
\mathbf{O}\end{array}$ & $\stackrel{\mathbf{B}}{\mathbf{O}}$ & $\begin{array}{r}365 \cdot 9 \\
1,415 \cdot 9\end{array}$ & $\begin{array}{r}343 \\
1,142\end{array}$ & $\begin{array}{l}0.94 \\
0 \cdot 81\end{array}$ & $\begin{array}{r}786 \\
3,179\end{array}$ & $\begin{array}{r}268 \\
1,062\end{array}$ & $\begin{array}{l}0 \cdot 34 \\
0 \cdot 33\end{array}$ \\
\hline Total & $\ldots$ & $3,454 \cdot 8$ & 3,455 & $1 \cdot 00$ & 7,209 & 2,678 & $0 \cdot 37$ \\
\hline
\end{tabular}

TABLE IV

FOETAL DEATH-RATE ACCORDING TO MATERNAL ABO AND Rh BLOOD GROUP (Data of Newcombe, 1963)

\begin{tabular}{|c|c|c|c|c|c|c|c|}
\hline \multirow{2}{*}{\multicolumn{2}{|c|}{$\begin{array}{l}\text { Descending Order of } \\
\text { Rh-positive Mothers }\end{array}$}} & \multicolumn{3}{|c|}{ Rh-positive Mothers } & \multicolumn{3}{|c|}{ Rh-negative Mothers } \\
\hline & & \multirow[b]{2}{*}{$\begin{array}{l}\text { Livebirths } \\
\text { (10 per cent. } \\
\text { Sample) }\end{array}$} & \multicolumn{2}{|c|}{ Foetal Deaths } & \multirow[b]{2}{*}{$\begin{array}{l}\text { Livebirths } \\
\text { (10 per cent. } \\
\text { Sample) }\end{array}$} & \multicolumn{2}{|c|}{ Foetal Deaths } \\
\hline$\underset{\text { Expected }}{\text { Order }}$ & $\begin{array}{c}\text { Order } \\
\text { Observed }\end{array}$ & & Number & Per cent. & & Number & Per cent. \\
\hline $\begin{array}{c}\mathbf{O} \\
\mathbf{B} \\
\mathbf{A} \\
\mathbf{A B}\end{array}$ & $\begin{array}{c}\mathbf{O} \\
\mathbf{B} \\
\mathbf{A} \\
\mathbf{A B}\end{array}$ & $\begin{array}{r}21,189 \\
6,064 \\
15,232 \\
1,829\end{array}$ & $\begin{array}{r}11,282 \\
3,001 \\
7,523 \\
860\end{array}$ & $\begin{array}{l}5 \cdot 32 \\
4 \cdot 95 \\
4 \cdot 94 \\
4 \cdot 70\end{array}$ & $\begin{array}{r}4,152 \\
1,152 \\
3,162 \\
320\end{array}$ & $\begin{array}{r}2,172 \\
613 \\
1,610 \\
199\end{array}$ & $\begin{array}{l}5 \cdot 22 \\
5 \cdot 32 \\
5 \cdot 09 \\
6 \cdot 22\end{array}$ \\
\hline Total & $\ldots$ & 44,314 & 22,666 & $5 \cdot 11$ & 8,786 & 4,594 & $5 \cdot 23$ \\
\hline
\end{tabular}


and $\mathrm{O} R$ h-negative mothers, but that, contrary to expectation, the $\mathrm{A} R \mathrm{R}$-negative mothers had the lowest, instead of the second-highest, foetal deathrate.

\section{BABIES}

On the basis of Levine's observation, Nevanlinna $(1952,1953)$ and Nevanlinna and Vainio (1956) put forward the hypothesis that, in general, ABOincompatible foetuses are unable to $\mathrm{Rh}$-immunize their mothers. This hypothesis was powerfully supported some years later by Woolf (1956-57), who declared that "the published work is consistent in all respects with the suggestion, put forward by several workers, that the immunizing foetus must always, or nearly always, be ABO-compatible"-see also Knox and Walker (1957), Clarke, Finn, McConnell, and Sheppard (1958), Levine (1958a, b), and Knox, Murray, and Walker (1960, 1961)-“"though once the mother is immunized the subsequent foetuses will be affected whether they are compatible or not" (cf. Cohen and Glass, 1959). On this basis the babies most liable to haemolytic disease of the newborn would (other things being equal) be those which are invariably ABO-compatible with their mothers-i.e. group $\mathrm{O}$ babies. This was recognized by Donohue and others (1954), who pointed out that their series contained an appreciable, though nonsignificant, excess of $\mathrm{O}$ babies as compared with babies of other ABO groups.

Similarly, as relatively more A than B babies, and $B$ than $\mathrm{AB}$ babies, are $\mathrm{ABO}$-compatible with their mothers, the expected descending order of relative incidence of babies with haemolytic disease of the newborn must be $\mathbf{O}-\mathbf{A}-\mathbf{B}-\mathbf{A B}$. This descending order is, in fact, found in the aggregate of the three series so far reported in which the groups of the babies are given (Table V), and it means that, as Woolf (1956-57) pointed out, $\mathrm{Rh}$-iso-immunization results in weak selection against the $O$ gene and strong selection in favour of the $B$ gene.

\section{ABO-COMPATIBLE BABIES}

In any affected family the first-affected baby is almost invariably preceded by at least one unaffected ABO-compatible baby, which latter appears to be necessary for sensitization of the mother to $R h$. Now in ABO-incompatible matings much less than half the babies, on average, are ABO-compatible, and accordingly it follows that, on average, much less than half the babies born in such matings will be capable of sensitizing their mothers to $R h$. The result is that (to take one example) ABO-compatible second-born babies in ABO-incompatible matings will have, on average, a much smaller chance of being affected with haemolytic disease of the newborn than they would have in the event of their being second-born children in ABO-compatible matings.

This argument is supported by the only series in which a direct comparison is possible-that of Cohen (1960)-for here the ratio of observed to expected ABO-compatible affected babies from ABO-incompatible matings (Table VI, overleaf) is, in the aggregate, very significantly lower than that for affected ABO-compatible babies from ABO-compatible matings (Brass, 1963)-viz. 0.97 (404: $416 \cdot 8)$ compared to $1 \cdot 15(2058: 1784 \cdot 8)$.

\section{ABO-COMPatible MOTHERS}

The argument of the last section has an implication for mothers. This is that, although all babies who are ABO-compatible with their mother are, in themselves, equally capable of immunizing their mothers against $\mathrm{Rh}$, they are far from equally liable to have mothers who are, in fact, $\mathrm{Rh}$-immunized, as some of these babies will have relatively more ABO-incompatible sibs than others. Thus, for example, ABOcompatible babies of $\mathbf{O}$ mothers will have, collectively, a lower relative incidence of haemolytic disease of the newborn than ABO-compatible babies of $\mathrm{A}$ mothers, as the proportion of $\mathrm{ABO}$-compatible

TABLE V

ABO BLOOD GROUP INCIDENCE OF BABIES WITH Rh HAEMOLYTIC DISEASE OF THE NEWBORN

\begin{tabular}{|c|c|c|c|c|c|c|c|}
\hline \multicolumn{2}{|c|}{$\begin{array}{l}\text { Descending Order of } \\
\text { Incidence of Babies }\end{array}$} & \multicolumn{3}{|c|}{$\begin{array}{c}\text { Combined Data of } \\
\text { Donohue and others (1954) and } \\
\text { Reepmaker (1955) }\end{array}$} & \multicolumn{3}{|c|}{ Data of Cohen (1960) } \\
\hline $\begin{array}{c}\text { Order } \\
\text { Expected }\end{array}$ & $\begin{array}{c}\text { Order } \\
\text { Observed }\end{array}$ & $\begin{array}{c}\text { Babies } \\
\text { Expected }\end{array}$ & $\begin{array}{l}\text { Babies } \\
\text { Observed }\end{array}$ & $\frac{\text { Observed }}{\text { Expected }}$ & $\begin{array}{l}\text { Babies } \\
\text { Expected }\end{array}$ & $\begin{array}{c}\text { Babies } \\
\text { Observed }\end{array}$ & $\frac{\text { Observed }}{\text { Expected }}$ \\
\hline $\mathbf{O}$ & $\mathbf{O}$ & $935 \cdot 4$ & 1,043 & $1 \cdot 12$ & $1,265 \cdot 4$ & 1,404 & $1 \cdot 11$ \\
\hline $\begin{array}{c}\mathbf{A} \\
\mathbf{B} \\
\mathbf{A B}\end{array}$ & $\begin{array}{c}\mathbf{A} \\
\mathbf{B} \\
\mathbf{A B}\end{array}$ & $\begin{array}{r}870 \cdot 5 \\
183 \cdot 6 \\
68 \cdot 9\end{array}$ & $\begin{array}{r}823 \\
150 \\
43\end{array}$ & $\begin{array}{l}0.95 \\
0.82 \\
0.62\end{array}$ & $\begin{array}{r}1,073 \cdot 8 \\
329 \cdot 8 \\
109 \cdot 2\end{array}$ & $\begin{array}{r}1,048 \\
252 \\
74\end{array}$ & $\begin{array}{l}0 \cdot 98 \\
0 \cdot 76 \\
0 \cdot 68\end{array}$ \\
\hline Total & $\ldots$ & $2,058 \cdot 4$ & 2,059 & $1 \cdot 00$ & $2,778 \cdot 2$ & 2,778 & $1 \cdot 00$ \\
\hline
\end{tabular}


TABLE VI

ABO-COMPATIBLE BABIES WITH Rh HAEMOLYTIC DISEASE OF THE NEWBORN (Data of Cohen, 1960)

\begin{tabular}{|c|c|c|c|c|c|c|}
\hline \multirow{2}{*}{$\begin{array}{l}\text { ABO Group } \\
\text { of Babies }\end{array}$} & \multicolumn{3}{|c|}{ ABO-Compatible Babies from ABO-Compatible Matings } & \multicolumn{3}{|c|}{ ABO-Compatible Babies from ABO-Incompatible Matings } \\
\hline & $\begin{array}{c}\text { Babies } \\
\text { Expected }\end{array}$ & $\begin{array}{c}\text { Babies } \\
\text { Observed }\end{array}$ & $\frac{\text { Observed }}{\text { Expected }}$ & $\begin{array}{c}\text { Babies } \\
\text { Expected }\end{array}$ & $\begin{array}{l}\text { Babies } \\
\text { Observed }\end{array}$ & $\frac{\text { Observed }}{\text { Expected }}$ \\
\hline AB & $17 \cdot 6$ & 25 & $1 \cdot 42$ & & & \\
\hline $\begin{array}{l}\mathbf{A} \\
\mathbf{O} \\
\mathbf{B}\end{array}$ & $\begin{array}{l}675 \cdot 0 \\
938 \cdot 0 \\
154 \cdot 2\end{array}$ & $\begin{array}{r}793 \\
1,076 \\
164\end{array}$ & $\begin{array}{l}1 \cdot 17 \\
1 \cdot 15 \\
1 \cdot 06\end{array}$ & $\begin{array}{r}54 \cdot 9 \\
327 \cdot 4 \\
34 \cdot 5\end{array}$ & $\begin{array}{r}48 \\
328 \\
28\end{array}$ & $\begin{array}{l}0.87 \\
1.00 \rightarrow \\
0.81\end{array}$ \\
\hline Total $\ldots$ & $1,784 \cdot 8$ & 2,058 & $1 \cdot 15$ & $416 \cdot 8$ & 404 & 0.97 \\
\hline
\end{tabular}

babies who have, collectively, ABO-incompatible sibs is very much greater for babies of $\mathrm{O}$ mothers than for babies of A mothers. This has been recognized by Reepmaker and others (1962), from an analysis of Reepmaker's earlier data (Reepmaker, 1955). The figures are given -along with those from the series of Cohen (1960)-in Tables VII to X. In Reepmaker's series the observed-expected ratio is very significantly higher for $\mathrm{ABO}$-compatible babies of $\mathrm{A}$ mothers than for $\mathrm{ABO}$-compatible babies of $\mathrm{O}$ mothers-viz. $1 \cdot 26(817: 647 \cdot 8)$ compared to $1 \cdot 04$ $(506: 485 \cdot 7)$-and in Cohen's series it is significantly higher-viz. $1 \cdot 19(1169: 986 \cdot 4)$ compared to $1.09(932: 854 \cdot 4)$.

Similarly, the expected descending order of relative incidence of mothers in ABO-compatible baby-mother combinations is $\mathbf{A B}-\mathbf{A}-\mathbf{B}-\mathbf{O}$, as the proportion of ABO-compatible babies who have, collectively, ABO-incompatible sibs is less for babies of $\mathrm{AB}$ mothers than of $\mathrm{A}$ mothers, of $\mathrm{A}$ than of $\mathrm{B}$ mothers, and of $B$ than of $O$ mothers.

This $\mathbf{A B}-\mathbf{A}-\mathbf{B}-\mathbf{O}$ descending order is not, however, found in either Reepmaker's or Cohen's series (Table VII), there being fewer AB mothers than expected in both series, and many more $\mathrm{O}$ mothers than expected in Cohen's series.

TABLE VII

INCIDENCE OF MOTHERS IN ABO-COMPATIBLE BABY-MOTHER COMBINATIONS

\begin{tabular}{|c|c|c|c|c|c|c|}
\hline \multirow{2}{*}{$\begin{array}{l}\text { Expected Descending } \\
\text { Order of Incidence } \\
\text { of Mothers }\end{array}$} & \multicolumn{3}{|c|}{ Data of Reepmaker (1955) } & \multicolumn{3}{|c|}{ Data of Cohen (1960) } \\
\hline & $\underset{\text { Expected }}{\text { Matings }}$ & $\begin{array}{l}\text { Matings } \\
\text { Observed }\end{array}$ & $\frac{\text { Observed }}{\text { Expected }}$ & $\underset{\text { Expected }}{\text { Matings }}$ & $\begin{array}{c}\text { Matings } \\
\text { Observed }\end{array}$ & $\frac{\text { Observed }}{\text { Expected }}$ \\
\hline $\begin{array}{l}\mathbf{A B} \\
\mathbf{A} \\
\mathbf{B} \\
\mathbf{O}\end{array}$ & $\begin{array}{l}53 \cdot 1 \\
647 \cdot 8 \\
102 \cdot 5 \\
485 \cdot 7\end{array}$ & $\begin{array}{r}47 \\
817 \\
122 \\
506\end{array}$ & $\begin{array}{l}0 \cdot 89 \rightarrow \\
1 \cdot 26 \\
1 \cdot 19 \\
1 \cdot 04\end{array}$ & $\begin{array}{l}109 \cdot 1 \\
986 \cdot 4 \\
251 \cdot 7 \\
854 \cdot 4\end{array}$ & $\begin{array}{r}121 \\
1,169 \\
240 \\
932\end{array}$ & $\begin{array}{l}1 \cdot 11 \rightarrow \\
1 \cdot 19 \\
0 \cdot 95 \\
1 \cdot 09 \rightarrow\end{array}$ \\
\hline
\end{tabular}

TABLE VIII

INCIDENCE OF ABO-COMPATIBLE BABY-MOTHER COMBINATIONS

\begin{tabular}{|c|c|c|c|c|c|c|}
\hline \multirow[b]{2}{*}{ Babies ex Mothers } & \multicolumn{3}{|c|}{ Data of Reepmaker (1955) } & \multicolumn{3}{|c|}{ Data of Cohen (1960) } \\
\hline & $\begin{array}{c}\text { Combinations } \\
\text { Expected }\end{array}$ & $\begin{array}{c}\text { Combinations } \\
\text { Observed }\end{array}$ & $\frac{\text { Observed }}{\text { Expected }}$ & $\begin{array}{c}\text { Combinations } \\
\text { Expected }\end{array}$ & $\begin{array}{l}\text { Combinations } \\
\text { Observed }\end{array}$ & $\frac{\text { Observed }}{\text { Expected }}$ \\
\hline $\begin{array}{r}\mathrm{B} \text { ex } \mathrm{AB} \\
\mathrm{A} \text { ex } \mathrm{AB} \\
\mathrm{AB} \text { ex } \mathrm{AB}\end{array}$ & $\begin{array}{r}19 \cdot 5 \\
24.9 \\
8.7\end{array}$ & $\begin{array}{r}23 \\
18 \\
6\end{array}$ & $\begin{array}{l}1 \cdot 18 \\
0.72 \\
0.69\end{array}$ & $\begin{array}{l}41 \cdot 4 \\
50 \cdot 1 \\
17 \cdot 6\end{array}$ & $\begin{array}{l}49 \\
47 \\
25\end{array}$ & $\begin{array}{l}1 \cdot 18 \\
0.94 \\
1 \cdot 42\end{array}$ \\
\hline $\begin{array}{l}\text { ex } A \\
A \text { ex } A\end{array}$ & $\begin{array}{l}193 \cdot 2 \\
454 \cdot 6\end{array}$ & $\begin{array}{l}253 \\
564\end{array}$ & $\begin{array}{l}1 \cdot 31 \\
1 \cdot 24\end{array}$ & $\begin{array}{l}306 \cdot 6 \\
679 \cdot 8\end{array}$ & $\begin{array}{l}375 \\
794\end{array}$ & $\begin{array}{l}1 \cdot 22 \\
1 \cdot 17\end{array}$ \\
\hline $\begin{array}{l}\mathrm{B} \text { ex } \mathrm{B} \\
\mathrm{O} \text { ex } \mathrm{B}\end{array}$ & $\begin{array}{l}57.6 \\
44.9\end{array}$ & $\begin{array}{l}70 \\
52\end{array}$ & $\begin{array}{l}1 \cdot 22 \\
1 \cdot 16\end{array}$ & $\begin{array}{l}147 \cdot 3 \\
104 \cdot 4\end{array}$ & $\begin{array}{r}143 \\
97\end{array}$ & $\begin{array}{l}0.97 \\
0.93\end{array}$ \\
\hline 0 ex 0 & $485 \cdot 7$ & 506 & $1 \cdot 04$ & $854 \cdot 4$ & 932 & $1 \cdot 09 \rightarrow$ \\
\hline
\end{tabular}


TABLE IX

INCIDENCE OF BABIES FROM ABO-COMPATIBLE MATINGS (Data of Cohen, 1960)

\begin{tabular}{|c|c|c|c|c|c|c|c|}
\hline \multicolumn{4}{|c|}{$\begin{array}{l}\text { ABO-Compatible Babies from Symmetrical } \\
\text { ABO-Compatible Matings }\end{array}$} & \multicolumn{4}{|c|}{$\begin{array}{l}\text { ABO-Compatible Babies from Asymmetrical } \\
\text { ABO-Compatible Matings }\end{array}$} \\
\hline Class & Expected & Observed & $\frac{\text { Observed }}{\text { Expected }}$ & Class & Expected & Observed & $\frac{\text { Observed }}{\text { Expected }}$ \\
\hline $\mathbf{A B}$ ex $\mathbf{A B} \times \mathbf{A B}$ & $2 \cdot 0$ & 5 & $2 \cdot 50$ & $\begin{array}{c}\mathbf{A B} \text { ex } \mathbf{A} \times \mathbf{B} \\
\mathbf{B} \text { ex } \mathbf{A} \times \mathbf{B} \\
\mathbf{A} \text { ex } \mathbf{A} \times \mathbf{A B}\end{array}$ & $\begin{array}{r}12 \cdot 1 \\
8 \cdot 9 \\
21 \cdot 0\end{array}$ & $\begin{array}{l}17 \\
12 \\
17\end{array}$ & $\begin{array}{l}1 \cdot 40 \\
1 \cdot 35 \\
0 \cdot 81\end{array}$ \\
\hline $\begin{array}{l}\mathbf{O} \text { ex } \mathbf{A} \times \mathbf{A} \\
\mathbf{A} \text { ex } \mathbf{A} \times \mathbf{A}\end{array}$ & $\begin{array}{r}74 \cdot 7 \\
343 \cdot 0\end{array}$ & $\begin{array}{l}131 \\
448\end{array}$ & $\begin{array}{l}1 \cdot 75 \\
1 \cdot 31\end{array}$ & $\begin{array}{l}\mathbf{O} \text { ex } \mathbf{O} \times \mathbf{A} \\
\mathbf{A} \text { ex } \mathbf{O} \times \mathbf{A}\end{array}$ & $\begin{array}{l}206 \cdot 9 \\
281 \cdot 9\end{array}$ & $\begin{array}{l}231 \\
298\end{array}$ & $\begin{array}{l}1 \cdot 12 \\
1 \cdot 06\end{array}$ \\
\hline $\begin{array}{l}\mathbf{B} \text { ex } \mathbf{A B} \times \mathbf{A B} \\
\mathbf{A} \text { ex } \mathbf{A B} \times \mathbf{A B}\end{array}$ & $\begin{array}{l}1 \cdot 0 \\
1 \cdot 0\end{array}$ & 1 & $\begin{array}{l}1 \cdot 00 \\
1 \cdot 00\end{array}$ & $\begin{array}{l}\mathbf{B} \operatorname{ex} \mathbf{O} \times \mathbf{A B} \\
\mathbf{A} \operatorname{ex} \mathbf{O} \times \mathbf{A B}\end{array}$ & $\begin{array}{l}25 \cdot 0 \\
25 \cdot 0\end{array}$ & $\begin{array}{l}30 \\
26\end{array}$ & $\begin{array}{l}1 \cdot 20 \\
1 \cdot 04\end{array}$ \\
\hline $\begin{array}{l}\mathrm{O} \text { ex } \mathrm{B} \times \mathrm{B} \\
\mathrm{B} \text { ex } \mathrm{B} \times \mathrm{B}\end{array}$ & $\begin{array}{r}8 \cdot 9 \\
33 \cdot 6\end{array}$ & $\begin{array}{l}18 \\
49\end{array}$ & $\begin{array}{l}2 \cdot 02 \\
1 \cdot 46\end{array}$ & $\begin{array}{l}\mathrm{O} \text { ex } \mathrm{O} \times \mathrm{B} \\
\mathrm{B} \text { ex } \mathrm{O} \times \mathrm{B}\end{array}$ & $\begin{array}{l}70 \cdot 5 \\
79 \cdot 2\end{array}$ & $\begin{array}{l}62 \\
66\end{array}$ & $\begin{array}{l}0.88 \\
0.83\end{array}$ \\
\hline $\mathrm{O}$ ex $\mathrm{O} \times \mathbf{O}$ & $577 \cdot 0$ & 634 & $1 \cdot 10$ & $\begin{array}{r}\mathbf{A} \text { ex } \mathbf{B} \times \mathbf{A B} \\
\mathrm{B} \text { ex } \mathbf{B} \times \mathbf{A B} \\
\mathbf{A B} \text { ex } \mathbf{B} \times \mathbf{A B}\end{array}$ & $\begin{array}{l}3 \cdot 1 \\
6 \cdot 5 \\
3 \cdot 5\end{array}$ & $\begin{array}{l}3 \\
6 \\
3\end{array}$ & $\begin{array}{l}0.97 \\
0.92 \\
0.88\end{array}$ \\
\hline Total $\ldots$ & $1,041 \cdot 2$ & 1,287 & $I \cdot 24$ & Total .. & $743 \cdot 6$ & 771 & $1 \cdot 04$ \\
\hline
\end{tabular}

TABLE X

INCIDENCE OF BABIES FROM ABO-INCOMPATIBLE MATINGS (Data of Cohen, 1960)

\begin{tabular}{|c|c|c|c|c|c|c|c|}
\hline \multicolumn{4}{|c|}{$\begin{array}{l}\text { ABO-Compatible Babies from } \\
\text { ABO-Incompatible Matings }\end{array}$} & \multicolumn{4}{|c|}{$\begin{array}{l}\text { ABO-Incompatible Babies from } \\
\text { ABO-Incompatible Matings }\end{array}$} \\
\hline \multirow{2}{*}{$\begin{array}{l}\text { Expected } \\
\text { Descending } \\
\text { Order of } \\
\text { Fathers }\end{array}$} & \multicolumn{3}{|c|}{ Number of Babies } & \multirow{2}{*}{$\begin{array}{l}\text { Expected } \\
\text { Descending } \\
\text { Order of } \\
\text { Fathers }\end{array}$} & \multicolumn{3}{|c|}{ Number of Babies } \\
\hline & Expected & Observed & $\frac{\text { Observed }}{\text { Expected }}$ & & Expected & Observed & $\frac{\text { Observed }}{\text { Expected }}$ \\
\hline $\begin{array}{l}A \text { ex } \mathbf{A B} \times \mathbf{A} \\
\mathbf{B} \text { ex } \mathbf{A B} \times \mathbf{B}\end{array}$ & $\begin{array}{r}21 \cdot 0 \\
6 \cdot 5\end{array}$ & $\begin{array}{r}21 \\
6\end{array}$ & $\begin{array}{l}1 \cdot 00 \\
0.92\end{array}$ & $\begin{array}{r}\mathbf{A B} \text { ex } \mathbf{A B} \times \mathbf{A} \\
\mathbf{B} \text { ex } \mathbf{A B} \times \mathbf{A} \\
\mathbf{A B} \text { ex } \mathbf{A B} \times \mathbf{B} \\
\mathbf{A} \text { ex } \mathbf{A B} \times \mathbf{B}\end{array}$ & $\begin{array}{r}12 \cdot 1 \\
8 \cdot 9 \\
3 \cdot 5 \\
3 \cdot 1\end{array}$ & $\begin{array}{l}8 \\
5 \\
3 \\
0\end{array}$ & $\begin{array}{r}0.66 \\
0.56 \\
0.86 \\
\infty\end{array}$ \\
\hline $\mathbf{A B}$ & $27 \cdot 5$ & 27 & 0.98 & AB & $27 \cdot 6$ & 16 & 0.58 \\
\hline $\begin{array}{l}O \text { ex } \mathbf{B} \times \mathbf{O} \\
\mathbf{A} \text { ex } \mathbf{B} \times \mathbf{A} \\
\mathbf{O} \text { ex } \mathbf{B} \times \mathbf{A}\end{array}$ & $\begin{array}{l}70 \cdot 5 \\
33 \cdot 9 \\
25 \cdot 0\end{array}$ & $\begin{array}{l}68 \\
27 \\
13\end{array}$ & $\begin{array}{l}0.96 \\
0.80 \\
0.52\end{array}$ & $\begin{array}{r}\mathrm{B} \text { ex } \mathrm{B} \times \mathbf{O} \\
\mathrm{B} \text { ex } \mathrm{B} \times \mathbf{A} \\
\mathrm{AB} \text { ex } \mathrm{B} \times \mathbf{A}\end{array}$ & $\begin{array}{l}79 \cdot 2 \\
28 \cdot 0 \\
38 \cdot 0\end{array}$ & $\begin{array}{l}37 \\
16 \\
17\end{array}$ & $\begin{array}{l}0.47 \\
0.57 \\
0.45\end{array}$ \\
\hline B & $129 \cdot 4$ & 108 & 0.83 & B & $145 \cdot 2$ & 70 & 0.48 \\
\hline $\begin{array}{l}\mathrm{O} \text { ex } \mathbf{A} \times \mathbf{O} \\
\mathrm{B} \text { ex } \mathrm{A} \times \mathrm{B} \\
\mathrm{O} \text { ex } \mathrm{A} \times \mathrm{B}\end{array}$ & $\begin{array}{r}206 \cdot 9 \\
28 \cdot 0 \\
25 \cdot 0\end{array}$ & $\begin{array}{r}230 \\
22 \\
17\end{array}$ & $\begin{array}{l}1 \cdot 11 \rightarrow \\
0 \cdot 79 \\
0 \cdot 68\end{array}$ & $\begin{array}{r}\mathbf{A} \text { ex } \mathbf{A} \times \mathbf{O} \\
\mathbf{A B} \text { ex } \mathbf{A} \times \mathbf{B} \\
\mathbf{A} \text { ex } \mathbf{A} \times \mathbf{B}\end{array}$ & $\begin{array}{r}281 \cdot 9 \\
38 \cdot 0 \\
33 \cdot 9\end{array}$ & $\begin{array}{r}182 \\
21 \\
18\end{array}$ & $\begin{array}{l}0.65 \rightarrow \\
0.55 \\
0.53\end{array}$ \\
\hline \multirow[t]{2}{*}{$\mathbf{A}$} & $259 \cdot 9$ & 269 & $1 \cdot 04 \rightarrow$ & $\mathbf{A}$ & $353 \cdot 8$ & 221 & $0.62 \rightarrow$ \\
\hline & & & & $\begin{array}{l}\mathbf{A} \text { ex } \mathbf{A B} \times \mathbf{O} \\
\mathbf{B} \text { ex } \mathbf{A B} \times \mathbf{O}\end{array}$ & $\begin{array}{l}25 \cdot 0 \\
25 \cdot 0\end{array}$ & $\begin{array}{l}7 \\
2\end{array}$ & $\begin{array}{l}0 \cdot 28 \\
0 \cdot 08\end{array}$ \\
\hline Total $\ldots$ & $416 \cdot 8$ & 404 & 0.97 & Total .. & $576 \cdot 6$ & 316 & 0.55 \\
\hline
\end{tabular}

ABO-InCOMPATIBLE FATHERS

The argument of the last section but one has an implication for ABO-incompatible fathers as well as for ABO-compatible mothers. As a small minority of group $\mathrm{A}$ fathers as a whole are of the genotype $A A$, the rest being $A O$, it follows that a (very small) majority of babies of $\mathrm{ABO}$-incompatible $\mathrm{A}$ fathersi.e. of fathers in the mating classes $\mathrm{A} \times \mathrm{O}$ and $\mathrm{A} \times \mathrm{B}$ will themselves belong to group $\mathrm{A}$, and so will be ABO-incompatible with their mothers. Of group B fathers as a whole, however, an even smaller minority are of the genotype $B B$, the rest being $B O$, and accordingly it follows that an even smaller majority of the babies of $B$ fathers as a whole will be ABO-incompatible with their mothers than is true of the babies of $\mathrm{A}$ fathers as a whole. As to $\mathrm{ABO}$-incompatible $\mathrm{AB}$ fathers, if one disregards the mating class $A B \times O$ (for the reason mentioned in the sections headed "Matings" and "Babies"), this leaves the mating classes $A B \times A$ and $A B \times B$. In these two classes, clearly, only one-half (exactly) of the babies will be ABO-incompatible with their 
mother. See also Reepmaker, Nijenhuis, and van Loghem (1954).

From these facts it follows, on the argument of the last section but one, that the expected descending order of relative incidence of fathers in affected ABO-incompatible mating classes (excluding the class $\mathbf{A B} \times \mathbf{O}$ ) must be $\mathbf{A B}-\mathbf{A}-\mathbf{B}$. (All group $\mathrm{O}$ fathers are, ipso facto, ABO-compatible.) Table XI, however, shows that this descending order is not found either in the series of Reepmaker (1955), in which there are slightly too many AB fathers, or in the combined series of Malone (1949), Davidsohn and others (1958), and Cohen (1960), in which there are slightly too many $\mathrm{A}$ fathers.

Brass (1963) points out that, in any event, though the argument of the last two paragraphs may be true in theory, it is only indirectly relevant in practice. "The effect", he says, "occurs differentially by blood group only through variations in the numbers of matings in which all of the children are ABO-incompatible. In matings where there are also ABO-compatible children the average proportion is one-half, independently of blood group. Therefore the ratios of observed-expected ABO-compatible children would not vary for the reason specified. It is true that a variation in the observed-expected ratios for $\mathrm{ABO}$-incompatible babies should occur, but the numerical effect would be slight, and would be unlikely to be detected with the numbers in Cohen's study". See also Reepmaker and others (1962).

Table $\mathrm{X}$ shows that, in the only series for which the necessary data are available - that of Cohen (1960) - the excess of ABO-incompatible A fathers mentioned at the end of the last paragraph but one is characteristic of both the ABO-compatible and the ABO-incompatible babies of such fathers. The Table also shows that these anomalies are due, very largely, to:

(1) An absolute and substantial excess of (ABOcompatible) $O$ babies from the mating class $A$ fathers $\times \mathbf{O}$ mothers;
(2) A relative and substantial excess of (ABO-incompatible) $\mathrm{A}$ babies from the same mating class.

This excess of babies from $\mathrm{A}$ father $\times \mathbf{O}$ mother matings reflects an excess of such matings themselves, which in turn exemplifies a general excess of $\mathbf{A}$ parents in Cohen's series ( $c f$. Newcombe, 1963).

\section{Non-White Populations}

The expected descending orders of relative incidence mentioned throughout this paper are not of general application. They refer only to populations in which $\mathbf{O}$ individuals (phenotypes) outnumber $\mathbf{A}$ individuals, and $\mathbf{A}$ individuals outnumber $\mathbf{B}$ individuals. This particular descending order is characteristic of all White populations, but in many African populations, for example, the Bs outnumber the As, and in some Indian populations the Bs outnumber the As, and the As outnumber the Os (Mourant, Kopeć, and Domaniewska-Sobczak, 1958), and all such variants would entail appropriate changes in the expected descending orders of relative incidence detailed above.

These variations have the important genetic consequence that, in populations in which the descending order of incidence of phenotypes is (for example) $\mathrm{B}-\mathrm{A}-\mathrm{O}$, selection against the $O$ gene, and selection in favour of the $B$ gene, must both be much weaker than in White populations, with their $\mathbf{O}-\mathbf{A}-\mathbf{B}$ descending order of phenotypes.

\section{Sex Ratio of Babies}

Donohue and others (1954) pointed out that, in their series of babies with Rh haemolytic disease of the newborn, the ratio of males to females is $1 \cdot 20$ : 1 , compared with $1.07: 1$ in their control series (Table XII, opposite). Similarly, in the series of affected babies of Cohen (1960), the sex ratio is $1 \cdot 11: 1$, compared to $1.03: 1$ in the controls, while in the series of affected babies of Walker (1961), it is $1 \cdot 11: 1$ compared with $1.06: 1$ in the controls, and in the series of secondborn, first-affected babies of Renkonen and Seppälä

TABLE XI

INCIDENCE OF ABO-INCOMPATIBLE FATHERS (EXCLUDING AB FATHERS $\times O$ MOTHERS) IN Rh HAEMOLYTIC DISEASE OF THE NEWBORN

\begin{tabular}{|c|c|c|c|c|c|c|}
\hline \multirow{2}{*}{$\begin{array}{c}\text { Expected Descending } \\
\text { Order of Incidence } \\
\text { of ABO-Incompatible } \\
\text { Fathers }\end{array}$} & \multicolumn{3}{|c|}{ Data of Reepmaker (1955) } & \multicolumn{3}{|c|}{$\begin{array}{l}\text { Combined Data of Malone (1949), } \\
\text { Davidsohn and others (1958), and Cohen (1960) }\end{array}$} \\
\hline & $\begin{array}{l}\text { Matings } \\
\text { Expected }\end{array}$ & $\begin{array}{l}\text { Matings } \\
\text { Observed }\end{array}$ & $\frac{\text { Observed }}{\text { Expected }}$ & $\begin{array}{l}\text { Mothers Not } \\
\text { Rh-Immunized }\end{array}$ & $\begin{array}{c}\text { Mothers } \\
\text { Rh-Immunized }\end{array}$ & $\frac{\text { Rh-Immunized }}{\text { Non-Immunized }}$ \\
\hline $\begin{array}{l}\mathbf{A B} \\
\mathbf{B} \\
\mathbf{A}\end{array}$ & $\begin{array}{r}29 \cdot 0 \\
135.0 \\
403 \cdot 0\end{array}$ & $\begin{array}{r}18 \\
88 \\
216\end{array}$ & $\begin{array}{l}0.62 \rightarrow \\
0.65 \\
0.54\end{array}$ & $\begin{array}{r}96 \\
487 \\
1,217\end{array}$ & $\begin{array}{r}35 \\
123 \\
334\end{array}$ & $\begin{array}{l}0 \cdot 36 \\
0 \cdot 25 \\
0 \cdot 27 \rightarrow\end{array}$ \\
\hline
\end{tabular}


TABLE XII

SEX RATIO OF BABIES IN Rh HAEMOLYTIC DISEASE OF THE NEWBORN

\begin{tabular}{|c|c|c|c|c|c|c|}
\hline \multirow[b]{2}{*}{ Authors } & \multicolumn{3}{|c|}{ Control Babies } & \multicolumn{3}{|c|}{ Test Babies } \\
\hline & Male & Female & $\frac{\text { Male }}{\text { Female }}$ & Male & Female & $\frac{\text { Male }}{\text { Female }}$ \\
\hline $\begin{array}{c}\text { Renkonen and Seppälä } \\
\text { (1962) } \ldots\end{array}$ & 30,232 & 28,456 & $1 \cdot 06$ & 108 & 75 & $1 \cdot 44$ \\
\hline $\begin{array}{l}\text { Donohue and others }(1954) \\
\text { Cohen }(1960) \\
\text { Walker }(1961) \\
\text { W }\end{array}$ & $\begin{array}{r}43,736 \\
2,457 \\
318,211\end{array}$ & $\begin{array}{r}41,039 \\
2,385 \\
299,822\end{array}$ & $\begin{array}{l}1 \cdot 07 \\
1 \cdot 03 \\
1 \cdot 06\end{array}$ & $\begin{array}{r}279 \\
1,938 \\
1,485\end{array}$ & $\begin{array}{r}233 \\
1,740 \\
1,339\end{array}$ & $\begin{array}{l}1 \cdot 20 \\
1 \cdot 11 \\
1 \cdot 11\end{array}$ \\
\hline $\begin{array}{l}\text { Renkonen and Seppälä } \\
\text { (1962) } \ldots\end{array}$ & 21,844 & 20,841 & $1 \cdot 05$ & 93 & 86 & $1 \cdot 08$ \\
\hline
\end{tabular}

(1962) the sex ratio is $1 \cdot 08: 1$ compared with $1 \cdot 05: 1$ in the controls. In none of these series is the difference significant, but the findings as a whole can be regarded as suggestive, indicating a need for further study. They are the more so in that, as Renkonen and Seppälä pointed out, the sex ratio of their parallel series of first-born, sensitizing, preimmunizing sibs of second-born, first-affected babies is significantly higher than that of their controls (1.44:1 and 1.06:1) (Table XII).

For the series of Donohue and others, the controls used in Table XII are the total male and female babies born in Toronto in 1947-52 (Sellers, 1962). For Cohen's series, the controls are her parallel series of babies of non-sensitized mothers. For Walker's series, the controls are the total male and female babies born in the Northern Region of England in 1950-60. For Renkonen and Seppälä's series of first and second-born babies, the controls are the total male and female first and second-born babies respectively born in Finland in 1959-60 (Kahanpää, 1962).

If these findings were confirmed they would be consistent with certain findings on the sex ratio of normal babies relative to ABO blood group. Thus, in the aggregate of all known series of White newborn babies in 1924-58, Allan (1959) found that the sex ratio of $\mathrm{O}$ babies-viz. $1 \cdot 11: 1(7,914: 7,148)$ was very significantly higher than that of $A$ babiesviz. $1 \cdot 03: 1(6,359: 6,158)$. He also found that the sex ratio of the babies of $\mathrm{AB}$ mothers-viz. $1 \cdot 26: 1$ $(667: 531)$ was significantly higher than that of the babies of non-AB mothers-viz. $1 \cdot 08: 1(16,130$ : 14,982). Now, if either of these findings were confirmed, one would expect, other things being equal, to find a higher-than-normal sex ratio in babies affected with haemolytic disease of the newborn, and also in their sensitizing sibs, by virtue of the fact that group $\mathrm{O}$ babies, and babies of group $\mathrm{AB}$ mothers, are the two kinds of baby most liable to be affected, and are also, by implication (Levine, 1958a, b; Renkonen and Seppälä, 1962), the two kinds of baby most likely to act as sensitizing agents.

The above findings would also be consistent with the finding of Allan (1958) that, in a series of 4,631 unselected White newborn babies, the sex ratio was significantly higher for Rh-positive than for $\mathrm{Rh}$ negative babies. The sex ratio was $1 \cdot 12: 1(1,964$ : 1,754) for Rh-positive babies and $0.93: 1$ (444: 473) for Rh-negative babies. On the other hand, the sex ratio was considerably lower for A Rh-positive babies of $\mathrm{A} \mathbf{R h}$-negative mothers than for $\mathbf{O} \mathbf{R h}$ positive babies of $\mathrm{O} R \mathrm{R}$-negative mothers, and this is inconsistent with the findings noted above, when these are considered in the light of Tables VIII and IX.

\section{SUMMARY}

In the aggregate of all known series of cases of maternal $\mathrm{Rh}$ iso-immunization in which are reported the ABO blood groups of the affected baby and of one or both of its parents, the following points are noted, in respect of White populations:

(1) That, in accordance with expectation, the descending order of relative incidence of fathers of affected babies is $\mathbf{O}-\mathbf{A}-\mathbf{B}-\mathbf{A B}$.

(2) That, in accordance with expectation, the descending order of relative incidence of mothers of affected babies is $\mathbf{A B}-\mathbf{A}-\mathbf{B}-\mathbf{O}$.

(3) That, in accordance with expectation, the descending order of relative incidence of affected babies is $\mathbf{O}-\mathbf{A}-\mathbf{B}-\mathbf{A B}$.

In the only published (White) series in which the necessary comparisons are possible the following points are noted:

(1) That, in accordance with expectation, the relative incidence of affected ABO-compatible babies 
from ABO-incompatible matings is (very significantly) lower than that of affected ABO-compatible babies from $\mathrm{ABO}$-compatible matings.

(2) That, contrary to expectation, the relative incidence of affected babies of ABO-incompatible A fathers as a whole is higher, instead of lower, than that of affected babies of ABO-incompatible $A B$ or $B$ fathers.

A further finding is that the ratio of male to female babies is higher than normal in all four series of affected babies for which the necessary data are available, and also in the only series of sensitizing babies reported so far.

Mention is made of some implications of the foregoing points in respect of non-White races.

I am grateful to Dr H. B. M. Lewis, Dr E. G. Knox, and $\mathrm{Mr}$ William Brass for helpful comment, to Mr Brass for his statistical assessment of the data, and to the late Dr A. M. C. Sinclair-Gieben for Dutch translation.

\section{REFERENCES}

Allan, T. M. (1958). Brit. med. J., 2, 248. (1959). Ibid., 1, 553.

Brass, W. (1963). Personal communication.

Chown, B. (1948). In "The Rh Factor". (Blood, Special Issue No. 2, p. 155.) Grune and Stratton, New York.

Clarke, C. A., Finn, R., McConnell, R. B., and Sheppard, P. M. (1958). Int. Arch. Allergy, 13, 380.

Cohen, B. H. (1960). Amer. J. hum. Genet., 12, 180. and Glass, B. (1959). J. med. Educ., 34, 414.

Davidsohn, I., Stern, K., and Mackeviciute, M. (1958). "Proc. VI int. Congr. Blood Transfusion, Boston, 1956", Bibl. haemat. (Basel), (Suppl. to Acta haemat.), No. 7, 1 .

Donohue, W. L., Mullinger, M. A., Cook, E. G., and Snelling, C. E. (1954). Amer. J. Obstet. Gynec., 67, 233. Grodecka, U., Marciniakówna, E., and Osińska, M. (1960). Arch. Immunol. Ter. dośw., 8, 225.

Heistö, H. (1955). Acta path. microbiol. scand., 36, 257.

Kahanpää, K. H. (1962). Personal communication.
Knox, E. G., Murray, S., and Walker, W. (1960), Ibid., $14,77$.

,,- - (1961). J. Obstet. Gynaec. Brit. Comm., 68,11 .

and Walker, W. (1957). Brit. J. prev. soc. med., 11, 126.

Levine, P. (1943). J. Hered., 34, 71.

(1958a). Hum. Biol., 30, 14.

(1958b). Amer. Anthrop., n.s. 60, No. 1, pt 2, p.14. Memoir No. 86. "Natural Selection in Man": Papers of the Wenner-Gren Supper Conference, University of Michigan, 1957', by J. C. Crow, P. Levine, C. S. Coon, and J. V. Neel, arranged by J. N. Spuhler.

- (1959). J. med. Educ., 34, 418.

(1962). Cited by Race and Sanger (1962).

Loghem, J. J. van, and Spaander, J. (1948). Rev. Hémat., 3, 276.

Lucia, S. P., and Hunt, M. L., (1950a). J. Lab. clin. Med., 35, 24.

,

Malone, R. H. (1949). Brit. J. prev. soc. Med., 3, 228.

Mourant, A. E., Kopeć, A. C., and DomaniewskaSobczak, K. (1958). "The ABO Blood Groups". Blackwell, Oxford.

Nevanlinna, H. R. (1952). Acta path. microbiol. scand., Suppl. 93, "Trans. X Scand. Congr. Path. Bact., Bergen, 1952", p. 402.

(1953). Ann. Med. exp. Biol. Fenn. (Suppl. 2), 31. 26. and Vainio, T. (1956). Vox. Sang. (Basel), 1 (n.s.), Newcombe, H. B. (1963). Amer. J. hum. Genet., 15, 449.

Race, R. R., and Sanger, R. (1962). "Blood Groups in Man", 4th ed. Blackwell, Oxford.

Reepmaker, J. (1955). "ABO Antagonisme en Morbus Haemolyticus Neonatorum." Thesis, Leiden University.

, Nijenhuis, L. E., and Loghem, J. J. van (1954). Vox Sang. (Basel), 4, 117.

Renkonen, K (1962). Amer. J. hum. Genet., 14, 185. Biol. Fenn., 40, 108.

Sellers, A. H. (1962). Personal communication.

Speiser, P., and Jancik, E. W. (1953). Klin. Wschr., 31, 995.

Walker, W. (1961). Personal communication.

Wiener, A. S., Nappi, R., and Gordon, E. B. (1953). Blood, 8, 1024.

Woolf, B. (1956-57). Acta genet. (Basel), 6, 519. 